\title{
Long-Term Course of Haemoglobin and Ferritin Values in High-Frequency Donors of Whole Blood and Double Erythrocyte Apheresis
}

\author{
Vildana Pehlic ${ }^{a}$ Thomas Volken $^{\mathrm{b}}$ Andreas Holbro ${ }^{\mathrm{a}, \mathrm{c}}$ Zuzana Jirout ${ }^{\mathrm{a}}$ \\ Beatrice Drexler ${ }^{a, c}$ Andreas Buser ${ }^{a, c}$ Laura Infanti ${ }^{a, c}$ \\ ${ }^{a}$ Regional Blood Transfusion Service, Swiss Red Cross, Basel, Switzerland; 'b School of Health Professions, \\ Zurich University of Applied Sciences, Winterthur, Switzerland; ' Division of Haematology, University Hospital Basel, \\ Basel, Switzerland
}

\section{Keywords}

High-frequency donors · Interdonation interval · Ferritin ·

Haemoglobin

\begin{abstract}
Background: High-intensity donation is a risk factor for iron deficiency in blood donors. Interdonation intervals for whole blood (WB) donation and double unit red blood cell apheresis (2RBC) vary among countries. We retrospectively evaluated the course of haemoglobin $(\mathrm{Hb})$ and ferritin values in men regularly donating WB 4 times a year or 2RBC twice a year (i.e., maximal frequency) over a period of 48 months. Methods: Data of male donors with 16 WB or 8 2RBC consecutive donations were analysed. The minimum $\mathrm{Hb}$ levels for WB donation and 2RBC apheresis (collection of $360 \mathrm{~mL}$ $\mathrm{RBC}$ ) were 135 and $140 \mathrm{~g} / \mathrm{L}$, respectively. There was no lower limit set for ferritin, and no iron was substituted. Results: We identified 294 WB (mean age 53 years, SD 11) and 151 2RBC donors (mean age 48 years, SD 9) who donated at a mean interval of 97 (SD 18) and 201 days (SD 32), respectively, between January 1, 2008, and December 31, 2013. At baseline, $\mathrm{Hb}$ and ferritin values were lower in WB donors compared to 2RBC donors, with a mean $\mathrm{Hb}$ of $153 \mathrm{~g} / \mathrm{L}$ (SD 13) versus 159 $\mathrm{g} / \mathrm{L}$ (SD 8) and a mean ferritin of $44 \mu \mathrm{g} / \mathrm{L}$ (SD 52) versus 73 $\mu \mathrm{g} / \mathrm{L}$ (SD 56; $p<0.001$ for both parameters), respectively. Ferritin was below $15 \mu \mathrm{g} / \mathrm{L}$ in $40 \mathrm{WB}(14 \%)$ and in 4 (3\%) 2 RBC donors. In WB donors, the mean $\mathrm{Hb}$ levels at baseline versus
\end{abstract}

karger@karger.com www.karger.com/tmh

Karger $\frac{1}{*}$ BOPEN ACCESS
(C) 2020 The Author(s)

Published by S. Karger AG, Basel

This is an Open Access article licensed under the Creative Common Attribution-NonCommercial-4.0 International License (CC BY-NC) (http://www.karger.com/Services/OpenAccessLicense), applicable to the online version of the article only. Usage and distribution for commercial purposes requires written permission. last donation showed no significant difference (153 vs. 152 $\mathrm{g} / \mathrm{L}, p=0.068)$, whereas the mean ferritin levels decreased significantly (44 vs. $35 \mu \mathrm{g} / \mathrm{L}, p<0.001$ ). The $2 \mathrm{RBC}$ donor group displayed a statistically different decrease in both the mean $\mathrm{Hb}$ levels ( 158 vs. $157 \mathrm{~g} / \mathrm{L} ; p<0.05$ ) and the mean ferritin levels (73 vs. $66 \mu \mathrm{g} / \mathrm{L} ; p=0.052)$. The lowest $\mathrm{Hb}$ was measured at the 11 th WB donation $(152 \mathrm{~g} / \mathrm{L} ; p<0.05)$ and at the 4th 2RBC apheresis ( $157 \mathrm{~g} / \mathrm{L} ; p<0.05)$. There was no deferral due to low $\mathrm{Hb}$ at any time. The lowest ferritin was shown at the 4th WB (37 $\mu \mathrm{g} / \mathrm{L})$ and at the 3rd 2RBC donation $(60 \mu \mathrm{g} / \mathrm{L})$, respectively. At the last visit, ferritin was below $15 \mu \mathrm{g} / \mathrm{L}$ in 23 WB donors (8\%) and in 22 RBC donors (1\%). Conclusions: High-intensity male donors with an interdonation interval of 12 weeks for WB donation and 24 weeks for 2 RBC apheresis maintain acceptable $\mathrm{Hb}$ levels and, after an initial decline, stable ferritin levels despite ongoing blood donation.

(c) 2020 The Author(s)

Published by S. Karger AG, Basel

\section{Introduction}

Due to the decreasing pool of active blood donors and the overall aging of the general population, one major challenge for blood banks will be to ensure a sufficient blood supply to patients [1]. To tackle this task, one strategy is increasing the frequency of blood donations by shortening the interdonation interval and thus collecting a greater number of blood units per donor. However, 
shorter intervals may expose blood donors to a higher risk of iron deficiency and deferral due to low haemoglobin (Hb) [2-4].

Iron deficiency is a major challenge for maintaining an active blood donor pool [5-7]. In the INTERVAL trial, the only randomised study conducted on the interdonation interval in whole blood (WB) donors, a blood donation frequency higher than the standard in the UK (12 weeks for men, 16 weeks for women) increased the number of blood products but also resulted in more frequent donation-related symptoms, deferrals due to low $\mathrm{Hb}$ and iron deficiency [5]. Strategies to prevent low $\mathrm{Hb}$ and iron deficiency anaemia, including a reduction of donation frequency, were implemented in many single institutions [8, 9] and are currently discussed at a regulatory level [10].

On the other hand, the introduction of longer interdonation intervals can have a negative impact on blood procurement [11], depending on the extent of the interval prolongation. Although the interval between donations is one of the strongest predictors of iron deficiency [12], current practices vary among national blood services as well as single blood collection facilities [13]. In the United States, both males and females are allowed to donate WB every 8 weeks and double red blood cells (2RBC) by apheresis every 16 weeks [14]. The European Directives require the same minimal interdonation interval $(8$ weeks) for WB donors and set a total limit of 6 and 4 donations yearly for males and females, respectively. At the same time, the Directives recommend 4 and 3 donations yearly for males and females, respectively, not to be exceeded. The minimum interval for $2 \mathrm{RBC}$ collection is 4 and 6 months for men and women, respectively [15].

Women of childbearing age, young persons aged 1618 years, and high-frequency donors are at the greatest risk of iron deficiency. These donors are more often deferred due to low $\mathrm{Hb}$ and are more likely to cease donating blood permanently $[7,16]$. However, there appears to be a small, not well defined subgroup of frequent donors who are able to maintain normal $\mathrm{Hb}$ levels despite low iron stores and repeated donations at the shortest interval possible [17].

In Switzerland, the minimum interval for WB donations is 10 weeks for both men and women, but following the European recommendations, the practice is to allow a maximum of 4 and 3 donations yearly, respectively. The interdonation interval for $2 \mathrm{RBC}$ apheresis is set at a "protective" frequency of 24 weeks for both sexes.

At our centre, the routine measurement of ferritin was implemented along with the introduction of $2 \mathrm{RBC}$ apheresis in January 2004. We performed a retrospective analysis of $\mathrm{Hb}$ and ferritin measurements in male blood donors who donated WB or 2RBC by apheresis at the maximum donation frequency of 4 and 2 times yearly, respectively, over a period of 48 months. The aim of the study was to describe the course of $\mathrm{Hb}$ and ferritin and the occurrence of deferrals due to low $\mathrm{Hb}$ in these highintensity blood donors.

\section{Materials and Methods}

\section{Subjects and Eligibility Criteria}

In this study, regular male WB donors aged $18-75$ years and $2 \mathrm{RBC}$ donors aged 18-65 years were included. Donor selection criteria in accordance with the Swiss regulations and the European Directives had to be fulfilled. Regarding the donors' age limits in Switzerland, eligibility of WB donors older than 65 years is subject to approval by a blood donation physician and may be extended up to the age of 75 . These donors are required to undergo regular medical evaluations every 2 years assessing their individual risk profile. The upper age limit for donations by apheresis is 65 years.

All subjects in the $2 \mathrm{RBC}$ group must have at least $1 \mathrm{WB}$ donation prior to their first $2 \mathrm{RBC}$ apheresis, and many of them were regular WB donors previously. Conversely, only a few WB donors had donated $2 \mathrm{RBC}$ by apheresis prior to the inclusion in the study. Complete data on the donation history was not available for every donor.

We searched our files for blood donors who donated at the shortest interval ( 12 weeks for WB and 24 weeks for $2 \mathrm{RBC}$ ) and found that the highest donation frequency was maintained for a period of 48 months by the majority of these subjects, and therefore focused our analysis on this period. Thus, we identified 445 donors (3.8\% of all male donors) who underwent 16 consecutive WB donations and 8 consecutive 2RBC apheresis over 48 months.

Platelet apheresis donors, those with hereditary haemochromatosis or any HFE gene mutation, if known, were excluded from the analysis. Also excluded were procedures that were not completed for any reason (i.e., because of local haematoma or technical issues).

The eligibility criteria for WB donors included a minimum $\mathrm{Hb}$ level of $135 \mathrm{~g} / \mathrm{L}$ and a minimum body weight of $50 \mathrm{~kg}$, while the $2 \mathrm{RBC}$ apheresis donors were required to have a $\mathrm{Hb}$ of at least 140 $\mathrm{g} / \mathrm{L}$ and a body weight of at least $70 \mathrm{~kg}$, approximately correlating with a total blood volume of $5 \mathrm{~L}$ or more.

Ferritin levels were not included in the eligibility criteria nor were they used for the selection of $2 \mathrm{RBC}$ donors. Thus, volunteers were accepted for WB or 2RBC donation independently of their iron stores. No iron supplementation was provided to donors at any time, but donors were not systematically asked whether they had any symptoms of iron deficiency or were taking iron supplements.

\section{Laboratory Testing}

At each visit, a complete blood count was performed from a pre-donation finger prick sample on a haematology analyser (Sysmex K-4500, Sysmex Digitana AG, Horgen, Switzerland). Ferritin was also measured at each visit from a venous blood sample collected at the beginning of each procedure with a chemiluminescence assay (Architect ci8200, Abbott Diagnostics, Abbott Park, IL, USA). Results were available the following day. Our ferritin reference ranges for men were $30-300 \mu \mathrm{g} / \mathrm{L}$.

\section{Donation Procedures, $R B C$, and Iron Loss}

For conventional WB donation, a volume of approximately 450 $\mathrm{mL}$ blood was collected with an additional $30 \mathrm{~mL}$ blood (approximately $14 \mathrm{~mL} \mathrm{RBC)} \mathrm{for} \mathrm{routine} \mathrm{testing.} \mathrm{The} \mathrm{corresponding} \mathrm{total}$ iron loss was about $240-260 \mathrm{mg}$, considering a loss of about $1 \mathrm{mg}$ per $1 \mathrm{~mL}$ RBC [18]. The minimum interdonation interval was 12 weeks. 
Table 1. Characteristics of the study population, number of donations and haemoglobin and ferritin values at the first and last donation of the observation period

\begin{tabular}{|c|c|c|c|}
\hline & WB donors & 2RBC donors & $p$ value \\
\hline $\begin{array}{l}\text { Donors, } n \\
\quad \text { Male donors, } n(\%) \\
\text { Included in the study, } n(\%)\end{array}$ & $\begin{array}{l}21,700 \\
11,772(54)^{\mathrm{a}} \\
294(1.3)^{\mathrm{a}}\end{array}$ & $\begin{array}{l}495 \\
495(100)^{\mathrm{b}} \\
151(31)^{\mathrm{b}}\end{array}$ & \\
\hline $\begin{array}{l}\text { Donations, } n \\
\quad \text { From male donors, } n(\%) \\
\text { From donors included in study, } n(\%) \\
\text { Donations prior to study, mean (SD), } n \\
\quad \text { Mean interval (SD), days }\end{array}$ & $\begin{array}{l}82,324 \\
52,721(64) \\
4,704(9) \\
68(40)^{\mathrm{c}} \\
97.4(17.8)\end{array}$ & $\begin{array}{l}2,394 \\
2,394(100) \\
1,208(50) \\
40(30)^{\mathrm{d}} \\
201.0(32.2)\end{array}$ & $\begin{array}{l}<0.001^{\mathrm{f}} \\
<0.001^{\mathrm{f}}\end{array}$ \\
\hline $\begin{array}{l}\text { Age, median (range), years } \\
\text { At 1st visit } \\
\text { At last visit }\end{array}$ & $\begin{array}{l}56(20-70) \\
60(24-74)\end{array}$ & $\begin{array}{l}48(23-63) \\
52(27-67)\end{array}$ & $<0.001^{\mathrm{g}}$ \\
\hline $\begin{array}{l}\mathrm{Hb} \\
\text { At 1st visit, mean (SD), g/L } \\
\text { At last visit, mean (SD), g/L } \\
\text { Subjects with low Hbe, } n\end{array}$ & $\begin{array}{l}153(13) \\
152(8) \\
0\end{array}$ & $\begin{array}{c}159(8) \\
157(9) \\
0\end{array}$ & $\begin{array}{l}<0.001^{\mathrm{f}} \\
<0.001^{\mathrm{f}}\end{array}$ \\
\hline $\begin{array}{l}\text { Ferritin, mean }(\mathrm{SD}), \mu \mathrm{g} / \mathrm{L} \\
\text { At } 1 \text { st visit } \\
\text { At last visit }\end{array}$ & $\begin{array}{l}44(52) \\
35(25)\end{array}$ & $\begin{array}{l}73(56) \\
66(55)\end{array}$ & $\begin{array}{l}<0.001^{\mathrm{f}} \\
<0.001^{\mathrm{f}}\end{array}$ \\
\hline $\begin{array}{l}\text { Ferritin at } 1 \mathrm{st} \text { visit, } n(\%) \\
\quad \geq 100 \mu \mathrm{g} / \mathrm{L} \\
\quad 51-99 \mu \mathrm{g} / \mathrm{L} \\
31-50 \mu \mathrm{g} / \mathrm{L} \\
16-30 \mu \mathrm{g} / \mathrm{L} \\
\quad \leq 15 \mu \mathrm{g} / \mathrm{L}\end{array}$ & $\begin{aligned} 18 & (6) \\
48 & (16) \\
85 & (29) \\
103 & (35) \\
40 & (14)\end{aligned}$ & $\begin{array}{l}38(25) \\
49(32) \\
44(29) \\
16(11) \\
4(3)\end{array}$ & $<0.001^{\mathrm{h}}$ \\
\hline $\begin{array}{l}\text { Ferritin at last visit, } n(\%) \\
\quad \geq 100 \mu \mathrm{g} / \mathrm{L} \\
\quad 51-99 \mu \mathrm{g} / \mathrm{L} \\
\quad 31-50 \mu \mathrm{g} / \mathrm{L} \\
16-30 \mu \mathrm{g} / \mathrm{L} \\
\leq 15 \mu \mathrm{g} / \mathrm{L}\end{array}$ & $\begin{array}{l}5(2) \\
80(27) \\
87(30) \\
99(33) \\
23(8)\end{array}$ & $\begin{array}{l}32(21) \\
74(49) \\
27(18) \\
16(11) \\
2(1)\end{array}$ & $<0.001^{\mathrm{h}}$ \\
\hline
\end{tabular}

${ }^{\mathrm{a}}$ Of the whole $\mathrm{WB}$ donors population. ${ }^{\mathrm{b}}$ Of the whole $2 \mathrm{RBC}$ donors population. ${ }^{\mathrm{c}}$ Out of these, 5 donations were $2 \mathrm{RBC}$ apheresis. ${ }^{\mathrm{d}}$ Out of these, 43 donations were $2 \mathrm{RBC}$ apheresis. ${ }^{\mathrm{e}}$ Lower than $135 \mathrm{~g} / \mathrm{L}$ for WB donors and lower than $140 \mathrm{~g} / \mathrm{L}$ for $2 \mathrm{RBC}$ donors. ${ }^{\mathrm{f}}$ Independent sample $t$ test. ${ }^{\mathrm{g}}$ Wilcoxon rank-sum test. ${ }^{\mathrm{h}}$ Fisher's exact test.

2RBC apheresis was performed with an ALYX device (FenwalBaxter, Zürich, Switzerland) programmed for the collection of 360 $\mathrm{mL} \mathrm{RBC}$, corresponding to approximately the RBC volume of two WB donations minus $40 \mathrm{~mL}$. Taking into account additional RBC losses due to sampling for routine tests (about $30 \mathrm{~mL} \mathrm{WB}, 14 \mathrm{~mL}$ $\mathrm{RBC}$ ) as well as residual cells in the collection set (a median of 26 $\mathrm{mL}$ WB, about $11 \mathrm{~mL} \mathrm{RBC}$ ) [19], we calculated that the amount of iron lost at each completed 2RBC collection was approximately $385 \mathrm{mg}$. Thus, the amount of iron removed during each 2RBC apheresis $(360 \mathrm{~mL})$ was about $148 \%$ of that removed with each WB donation. The interval between two $2 \mathrm{RBC}$ aphereses was 24 weeks. No plasma or platelets were concomitantly collected.

\section{Statistical Analysis}

We used generalised estimating equation models of the Gaussian family with robust SEs in order to assess the temporal trajectories of $\mathrm{WB}$ and $2 \mathrm{RBC}$ donors' $\mathrm{Hb}$ and ferritin over 16 and 8 donations, respectively. Baseline $\mathrm{Hb}$ and ferritin at first donation were compared to subsequent measurements. Temporal changes in outcomes unadjusted and adjusted for age were reported both in the whole study cohort and in quartile groups defined by different $\mathrm{Hb}$ and ferritin values. Statistical significance was established at $p<$ 0.05. A Stata version 15.1 (StataCorp, College Station, TX, USA) was used for all statistical analyses.

\section{Results}

Between January 1, 2008, and December 31, 2013, the overall number of WB collections at our centre was 82,324 from 21,700 donors. Of these, 11,772 were males (54\% of all WB blood donors), who provided 52,721 WB donations ( $64 \%$ of all WB donations). The $2 \mathrm{RBC}$ donor pool comprised 495 male subjects and no females. The overall 


\section{Whole blood donors}
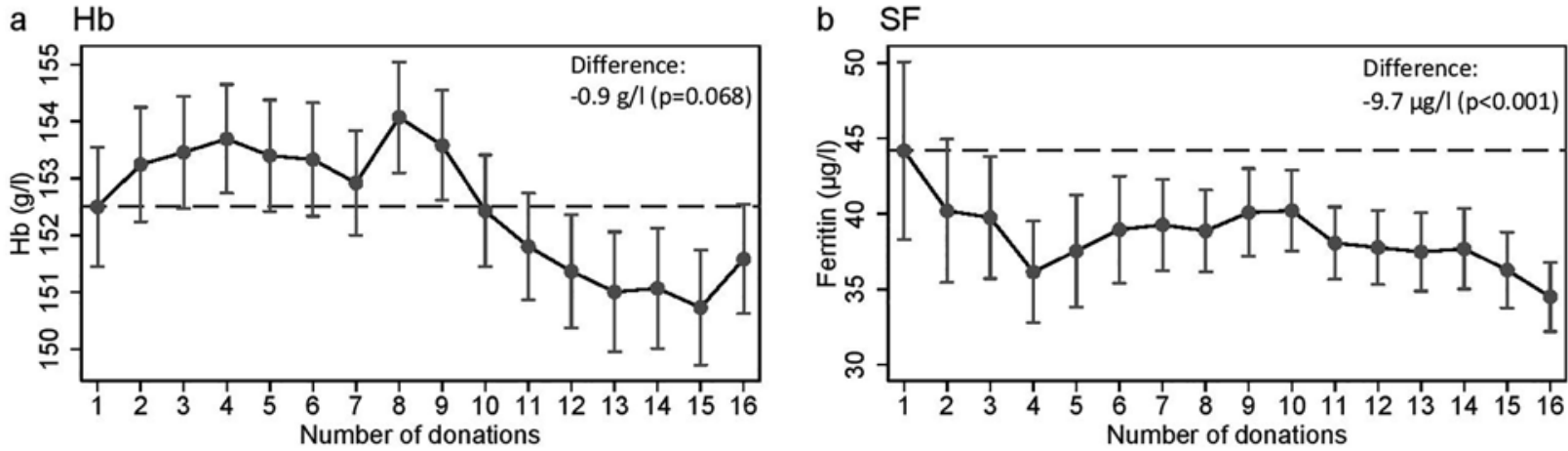

\section{Double red blood cell donors}
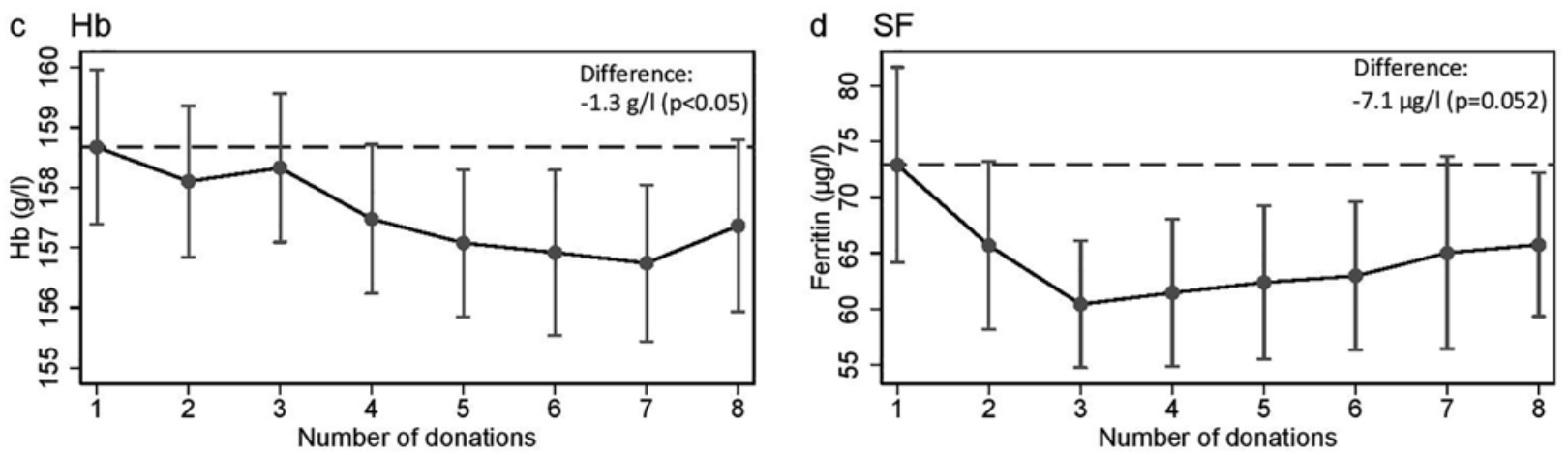

Fig. 1. Course of haemoglobin and ferritin in whole blood (a-b) and double red blood cell donors (c-d). Values are adjusted for age.

number of $2 \mathrm{RBC}$ aphereses performed within the study period was 2,394 (Table 1).

Characteristics of the Study Cohort and Values at the

First and at the Last Donation (Table 1)

In the study cohort, there were $294 \mathrm{WB}$ donors (1.3\% of all male WB donors, $66 \%$ of the study population) and $1512 \mathrm{RBC}$ donors $(31 \%$ of all $2 \mathrm{RBC}$ donors, $34 \%$ of the study population). The cohort donors provided a total of $4,704 \mathrm{WB}$ donations at a mean interval of 97.4 days (SD 17.8 ) and 1,208 2RBC aphereses at a mean interval of 201 days (SD 32.2).

At baseline, the 2 groups were different with respect to median age (WB donors: 56 years, range $20-70$ years; 2RBC donors: 48 years, range $23-63$ years; $p<0.001$ ) and to the mean number of donations performed prior to the first procedure in the study (68 in WB donors and 40 in 2RBC donors; $p<0.001$ ). In addition, both $\mathrm{Hb}$ (mean 153 g/L, SD 13 vs.159 g/L, SD 8) and ferritin (mean $44 \mu \mathrm{g} / \mathrm{L}$, SD 52 vs. $73 \mu \mathrm{g} / \mathrm{L}$, SD 56) were significantly lower in WB donors ( $p<0.001$ for both parameters).
While all donors fulfilled the $\mathrm{Hb}$ requirements, a broad range of ferritin values was observed in both groups. Ferritin was above $100 \mu \mathrm{g} / \mathrm{L}$ in $25 \%$ of $2 \mathrm{RBC}$ donors, but in only $6 \%$ of WB donors. The majority of WB donors (35\%) had ferritin levels between 16 and $30 \mu \mathrm{g} / \mathrm{L}$, while most $2 \mathrm{RBC}$ donors (32\%) had values between 51 and $99 \mu \mathrm{g} / \mathrm{L}$. Forty WB donors (14\%) but only 4 2RBC donors (3\%) had ferritin values below $15 \mu \mathrm{g} / \mathrm{L}$ indicating profound iron deficiency. Of the donors with very low ferritin values, those donating WB had a mean of WB donations prior to the study slightly lower than the overall mean of the WB group, while the $42 \mathrm{RBC}$ donors had a mean of previous WB donations that was higher than that of the whole 2RBC group (data not shown). Neither group had donated $2 \mathrm{RBC}$ by apheresis before the inclusion to the study.

At the last visit, the proportion of subjects with ferritin values between 16 and $30 \mu \mathrm{g} / \mathrm{L}$ slightly decreased (to 33\%) in the WB group and remained unchanged in the $2 \mathrm{RBC}$ group. The percentage of donors with values below 15 $\mu \mathrm{g} / \mathrm{L}$ dropped in both WB (8\%) and 2RBC donors (1\%). 

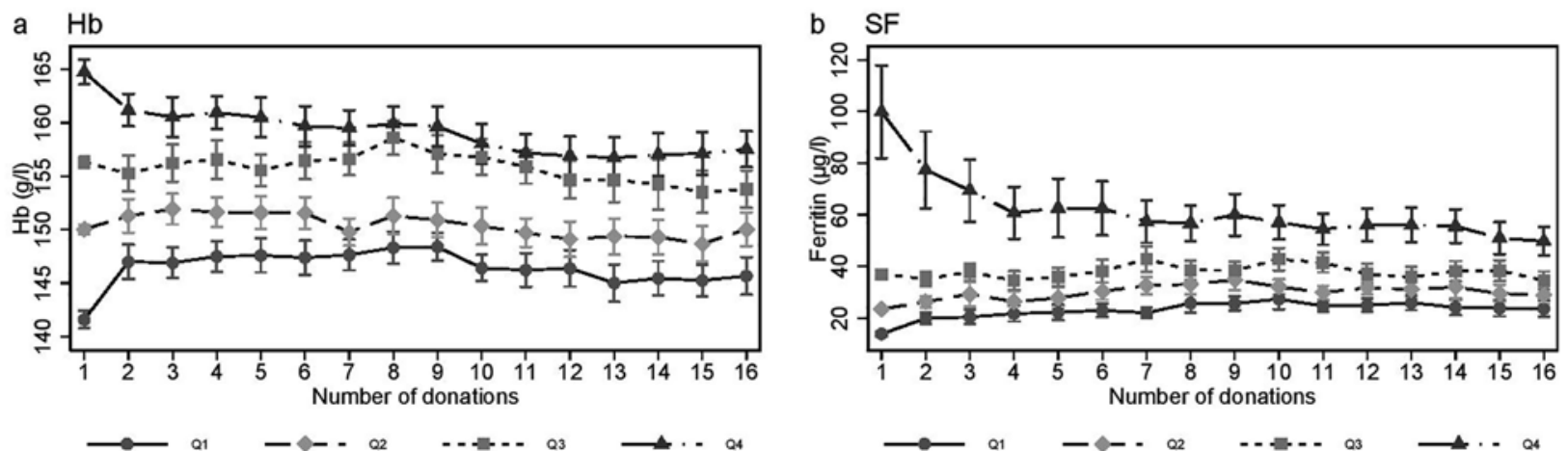

\section{Double red blood cell donors}
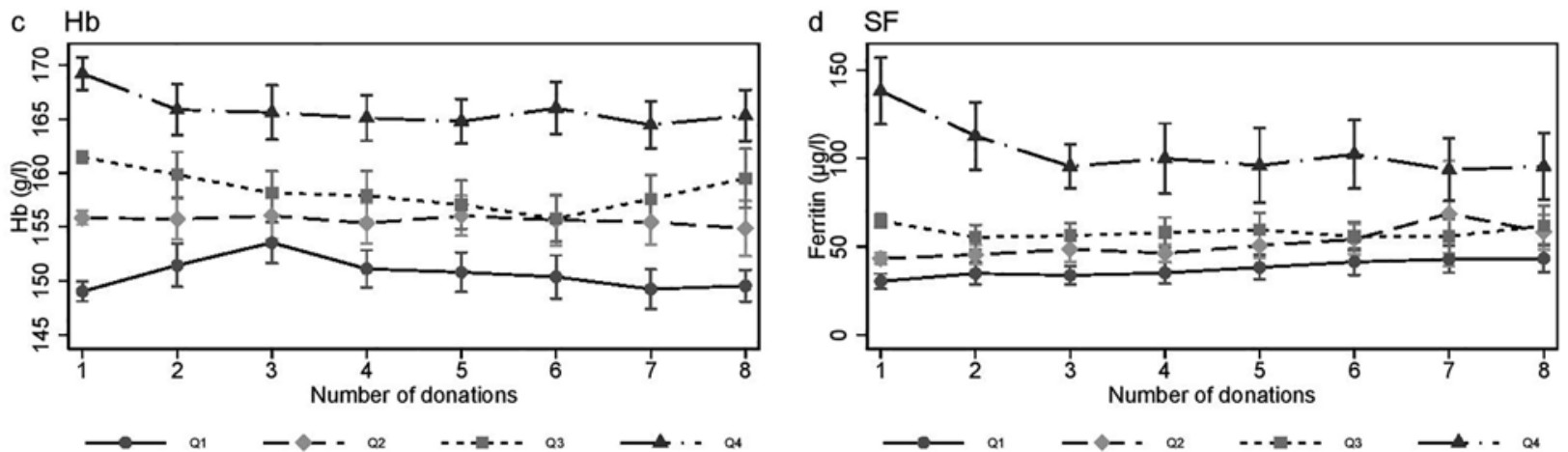

Fig. 2. Trajectories of haemoglobin and ferritin in whole blood (a-b) and double red blood cell donors (c-d) by quartile groups.

\section{Course of $\mathrm{Hb}$ and Ferritin}

Figure $1 \mathrm{a}-\mathrm{d}$ shows the values of $\mathrm{Hb}$ and ferritin over a period of 48 months adjusted for age. In WB donors, $\mathrm{Hb}$ declined from 153 to $152 \mathrm{~g} / \mathrm{L}(p=0.068)$ and ferritin from 44 to $35 \mu \mathrm{g} / \mathrm{L}(p<0.001)$, while in $2 \mathrm{RBC}$ donors $\mathrm{Hb}$ and ferritin decreased from 158 to $157 \mathrm{~g} / \mathrm{L}(p<0.05)$ and from 73 to $66 \mu \mathrm{g} / \mathrm{L}(p=0.052)$, respectively. Hb and ferritin differences between donation groups remained stable, with substantially higher levels of both $\mathrm{Hb}$ (mean $5 \mathrm{~g} / \mathrm{L}$ ) and ferritin (mean $26 \mu \mathrm{g} / \mathrm{L}$ ) in $2 \mathrm{RBC}$ donors. Compared to $\mathrm{Hb}$ at baseline, in $\mathrm{WB}$ donors a statistically significant $\mathrm{Hb}$ drop was observed from the 11th visit on $(152 \mathrm{~g} / \mathrm{L}, p<$ $0.05)$, that is, approximately after 33 months. Correspondingly, the lowest $\mathrm{Hb}$ values in $2 \mathrm{RBC}$ donors were observed from the 4 th donation on $(157 \mathrm{~g} / \mathrm{L}, p<0.05)$, that is, approximately after 24 months. Hb declined further in both groups until the 15th (minimal value: 151 $\mathrm{g} / \mathrm{L}$ ) and 7 th donation (minimal value: close to $157 \mathrm{~g} / \mathrm{L}$ ), respectively, with an increasing trend afterwards. However, the Hb levels have never reached their baseline levels in either group within the 48 months. On average, $\mathrm{Hb}$ levels remained $5 \mathrm{~g} / \mathrm{L}$ (95\% CI 3.7-6.4, $p<0.001$ ) higher in $2 \mathrm{RBC}$ donors compared to $\mathrm{WB}$ donors over the entire study period.

Ferritin levels in WB donors decreased from $44 \mu \mathrm{g} / \mathrm{L}$ at the first visit to $35 \mu \mathrm{g} / \mathrm{L}(p<0.001)$ at the last donation, and in $2 \mathrm{RBC}$ donors from 73 to $66 \mu \mathrm{g} / \mathrm{L}(p=0.052)$. Relative to baseline, a first significant ferritin drop in WB donors was observed already at the 2 nd donation $(41 \mu \mathrm{g} / \mathrm{L})$, after approximately 3 months, followed by a second decline at the 4 th visit, approximately 12 months later $(37 \mu \mathrm{g} / \mathrm{L}, p<0.001)$. From there on, a parabolic trend was observed, with a peak at the 10th donation and a consecutive drop (Fig. 1b). Similarly, ferritin significantly decreased in $2 \mathrm{RBC}$ donors at the 2 nd donation $(66 \mu \mathrm{g} / \mathrm{L})$, after approximately 12 months, reaching the lowest level at the 3rd donation $(60 \mu \mathrm{g} / \mathrm{L})$ after 18 months. From that point, ferritin values increased and reached $66 \mu \mathrm{g} / \mathrm{L}(p=0.052)$ at the end of the study period. Ferritin levels were also lower at the last visit compared to those at baseline in both groups, and were on average higher in $2 \mathrm{RBC}$ donors (mean $26 \mu \mathrm{g} / \mathrm{L}$; 95\% CI $19.3-32.7 \mu \mathrm{g} / \mathrm{L} ; p<0.001)$ over the entire observation period (Fig. 2b, d). 
We further assessed the trajectories of $\mathrm{Hb}$ and ferritin in quartile groups (Fig. 2a-d). For WB and 2RBC donors alike, we consistently found that $\mathrm{Hb}$ and ferritin declined most steeply in subjects with the highest baseline values (Q4). In $\mathrm{WB}$ donors of $\mathrm{Q} 4, \mathrm{Hb}$ declined in the range of $3.5-8.0 \mathrm{~g} / \mathrm{L}$, while in $2 \mathrm{RBC}$ donors, the decrease was $3.3-4.7 \mathrm{~g} / \mathrm{L}$. The corresponding ferritin drop was in the range of 22.5-50.1 $\mu \mathrm{g} / \mathrm{L}$ in $\mathrm{WB}$ donors and $25.5-44.6 \mu \mathrm{g} / \mathrm{L}$ in $2 \mathrm{RBC}$ donors.

Conversely, in donors with the lowest levels at first donation (Q1) values tended to improve with time. More specifically, $\mathrm{Hb}$ in $\mathrm{Q} 1$ significantly increased in the range of 3.7-6.0 g/L in the WB group and of $0.2-4.5 \mathrm{~g} / \mathrm{L}$ in the $2 \mathrm{RBC}$ group, while the ferritin increase was in the range of 6.1-13.5 and 3.4-13.0 $\mu \mathrm{g} / \mathrm{L}$, respectively. As compared to Q1 and Q4, the 2 intermediate quartile groups (Q2 and Q3) displayed a more stable trajectory of both $\mathrm{Hb}$ and ferritin, and values showed smaller differences from those at baseline.

\section{Discussion}

This study describes the course of $\mathrm{Hb}$ and iron stores in a selected population of high-intensity male blood donors undergoing regular $\mathrm{WB}$ or $2 \mathrm{RBC}$ donations at the shortest interdonation interval recommended in Switzerland. Most interestingly, these subjects did not show a drop in $\mathrm{Hb}$ below the acceptance limit over the 4 years' period of donating on a regular basis regardless of their iron stores including profound iron deficiency (ferritin below $15 \mu \mathrm{g} / \mathrm{L}$ ).

Previous large studies reported ferritin values lower than $10-12 \mu \mathrm{g} / \mathrm{L}$ in a substantial proportion of regular blood donors, ranging from $15 \%$ in the RISE study [20] to over $26 \%$ at our centre [9]. In the vast majority of WB donors, a minimum interval of 8 weeks, as currently adopted in the United States, is not sufficient for restoring $\mathrm{Hb}$ and iron stores, and is often associated with deferrals due to low $\mathrm{Hb}$ unless iron supplementation is given [12]. However, reducing the maximum donation frequency may not be alone sufficient to prevent relevant iron deficiency in blood donors. As shown by our data, despite a lower donation frequency in Switzerland compared to that of many other countries, ferritin values below 30 $\mu \mathrm{g} / \mathrm{L}$ were found in over one-third (35\%) of male donors and about $10 \%$ had values below $15 \mu \mathrm{g} / \mathrm{L}$.

On the other hand, Mast et al. [17] described a self-selected population of 138 high-intensity male and female blood donors who did not develop anaemia despite very low ferritin levels. The mechanism of "resistance" to iron deficiency anaemia observed in these "superdonors" was not completely elucidated through extensive evaluation, including hepcidin measurement and testing for HFE mutations [17]. It is possible that a significant proportion of the donors selected for our study may share some characteristics of the above-mentioned superdonors. Considering that in the study by Mast et al. [17] the interdonation interval was 8 weeks, most subjects in our cohort may possibly tolerate even more frequent blood donation schedules than currently recommended in Switzerland (4 WB donations yearly). Similar postulations may apply to the interval between two $2 \mathrm{RBC}$ aphereses. Our procedure for $2 \mathrm{RBC}$ apheresis (collection volume of $360 \mathrm{~mL}$ and interval of 24 weeks) appears to be particularly protective regarding iron loss. Although previous studies showed an insufficient recovery of iron stores with intervals of 16 weeks in the absence of iron supplementation $[21,22]$, it is possible that many of the $2 \mathrm{RBC}$ donors in our cohort may tolerate aphereses at a 16-weeks' frequency without developing low $\mathrm{Hb}$. With this respect, it is important to consider the differences in baseline characteristics of WB and 2RBC donors and also in the types of donation described in our study. 2RBC donors were younger, had higher $\mathrm{Hb}$ and ferritin levels at baseline, and had a lower number of previous blood donations (a mean of 40 vs. 68 in WB donors). These differences may be explained by the more recent recruitment of $2 \mathrm{RBC}$ donors following the introduction of $2 \mathrm{RBC}$ apheresis at our centre in 2004 as well as by different $\mathrm{Hb}$ cut-offs required for the 2 types of collections $(140 \mathrm{~g} / \mathrm{L}$ for $2 \mathrm{RBC}$ apheresis vs. $135 \mathrm{~g} / \mathrm{L}$ for $\mathrm{WB}$ donation). $\mathrm{Hb}$ and ferritin levels in 2RBC donors remained higher throughout the observation period, which is most probably explained by the fact that the RBC volume and iron amount lost with $2 \mathrm{RBC}$ apheresis are less than that of two WB donations. Another interesting finding is that $2 \mathrm{RBC}$ donors were much more likely to donate at the maximum frequency compared to WB donors (31 vs. 1.3\%). This data does not support the concern that a longer interdonation interval may induce a loss of motivation and a lower donor return [23].

The overall changes of $\mathrm{Hb}$ and ferritin observed within our study were similar in both types of blood donations. An initial drop in the values was followed by an upward trend later, even though the baseline levels of neither parameter were regained in neither group by the end of the study. Gonzàlez et al. [24] described a very similar course of ferritin in 2RBC donors over regular apheresis at an interval of 24 weeks. Also in that study, ferritin levels recovered after an initial significant decline, and so the authors concluded that ferritin is possibly not the most important parameter for $2 \mathrm{RBC}$ donor selection.

Since we included only experienced blood donors in the study, the number of previous donations had an impact on $\mathrm{Hb}$ and ferritin values at the baseline visit, but complete data on the donation history could not be retrieved for each donor. Therefore, we chose to analyse results separately in groups defined not by the number of previous donations but by baseline $\mathrm{Hb}$ and ferritin levels (quartiles). Particularly interesting is the favourable 
course of $\mathrm{Hb}$ and ferritin in subjects starting with the lowest values (Q1) in both donation groups. One could hypothesise that this subgroup in particular shares some metabolic characteristics of the "superdonors." Identifying these subjects prospectively in a given donor pool is probably not possible. Indeed, in our study these subjects represented only a very small fraction of the WB and $2 \mathrm{RBC}$ donors (1.3 and 2.5\%, respectively). However, we believe that these numbers underestimate the actual proportion of potential high-frequency donors who may provide a highest yield of blood products in the long-term. This aspect has a particular relevance when considering the generally declining number of active blood donors and the overall observed low donation frequency. At our centre, active blood donors represent about $4.1 \%$ of all potentially eligible adults living in our region, and give on average 1.5 donations yearly, for a total of about $15,000 \mathrm{WB}$ donations yearly. The number of $2 \mathrm{RBC}$ apheresis is steeply declining (over 300 per year in 2008-2013 and 108 in 2018). During the period of our analysis, from 2008 to 2013, there was approximately $1 \mathrm{WB}$ donation and 0.8 $2 \mathrm{RBC}$ donations per year for the total donor population. As also discussed by Di Angelantonio et al. [5], identifying donors who best tolerate more frequent donations would provide a valuable tool for enabling more flexible interdonation intervals. Since it is evident that no fixed interval can be applied to all donors alike, defining individualised donation frequencies may be the most appropriate approach for retaining and protecting donors. However, such a strategy requires a more precise characterisation of the actual risk for iron deficiency and low $\mathrm{Hb}$ in distinct blood donor groups, as we attempted in our analysis.

Based on our observations, $\mathrm{Hb}$ and ferritin values display different courses in distinct groups of regular blood donors, which may have potentially significant implications for donor care. First, it allows for a more correct interpretation of the initial variations of values (e.g., steeper drop of ferritin in subjects starting at higher levels, as shown by our data). Second, it demonstrates that low ferritin does not necessarily impact sustained blood donation and requires no intervention in subjects with sufficient $\mathrm{Hb}$ levels. With this respect, however, it would be important to evaluate specifically the presence of iron deficiency-related symptoms in donors with low ferritin levels. It is important to consider that prolonged iron deficiency even in the absence of symptoms and despite normal $\mathrm{Hb}$ levels may possibly negatively impair donors' health. Although the long-term effects of iron deficiency without anaemia are still unclear and are most probably influenced by individual differences, repetitive blood donation in iron-depleted subjects may represent a potential harm. In addition, recent data, although not conclusive, indicate that also the quality of $\mathrm{RBC}$ products can be altered by the donor's low iron stores. In the study by
Kanias et al. [25], donation intensity and ferritin levels correlated negatively with the RBC susceptibility to oxidative haemolysis during storage, but haemolysis was also mitigated if the donor received iron substitution. Another study in animal models demonstrated that RBC collected from mice with iron deficiency had a significantly shorter survival during storage and after transfusion [26].

A routine ferritin measurement creates undoubtedly valuable data that may help optimise donation frequency in individual donors [6]. This approach however cannot be easily put into practice in all blood donation facilities as it has logistic and financial implications. Prediction models for assessing the likelihood of donors' deferral due to low $\mathrm{Hb}$ using previous $\mathrm{Hb}$ levels and disregarding ferritin have been proposed $[2,6]$. These tools may prove helpful to identify potential high-frequency donors. In our opinion, further studies are needed to validate such models in large cohorts and in different donor groups.

Our study has the limitations of a retrospective analysis. In addition, the study population is small and has clear selection bias. All subjects of the cohort were males, the vast majority were middle-aged with very few young donors, and all were experienced donors with a variable number of previous donations. Thus, our results cannot be generalised to other blood donor groups, such as females and in particular pre-menopausal women and donors younger than 25 years. It is also not known with certainty whether some donors of our cohort took iron supplements without our knowledge, and information on symptoms of iron deficiency was not systematically collected. On the other hand, the homogeneous characteristics of the study cohort as well as the consistency of management of donors over time represent the strengths of our analysis.

In conclusion, $\mathrm{Hb}$ and ferritin values reflect characteristic patterns in high-frequency male WB or $2 \mathrm{RBC}$ donors over time and indicate the possibility of increasing donation frequency in a subgroup of subjects, with clear advantages on the procurement of blood products.

\section{Statement of Ethics}

The approval for this study was granted by the Ethikkomission Nordwest- und Zentralschweiz, Project ID 2019-01752.

\section{Conflict of Interest Statement}

The authors have no potential conflicts of interest to disclose.

\section{Author Contributions}

L.I. and V.P.: conception of the study and writing of the manuscript. V.P. and Z.J.: data collection. T.V.: statistics. All authors: manuscript revision and final approval. 


\section{References}

1 Williamson LM, Devine DV. Challenges in the management of the blood supply. Lancet. 2013 May;381(9880):1866-75.

2 Baart AM, van den Hurk K, de Kort WL. Minimum donation intervals should be reconsidered to decrease low hemoglobin deferral in whole blood donors: an observational study. Transfusion. 2015 Nov;55(11):2641-4.

3 Simon TL, Garry PJ, Hooper EM. Iron stores in blood donors. JAMA. 1981 May;245(20): 2038-43.

4 Smith GA, Fisher SA, Dorée C, Roberts DJ. A systematic review of factors associated with the deferral of donors failing to meet low haemoglobin thresholds. Transfus Med. 2013 Oct;23(5):309-20.

5 Di Angelantonio E, Thompson SG, Kaptoge S, Moore C, Walker M, Armitage J, et al.; INTERVAL Trial Group. Efficiency and safety of varying the frequency of whole blood donation (INTERVAL): a randomised trial of 45000 donors. Lancet. 2017 Nov;390(10110): 2360-71.

6 O’Meara A, Infanti L, Stebler C, Ruesch M, Sigle JP, Stern M, et al. The value of routine ferritin measurement in blood donors. Transfusion. 2011 Oct;51(10):2183-8.

7 Rigas AS, Sørensen CJ, Pedersen OB, Petersen MS, Thørner LW, Kotzé S, et al. Predictors of iron levels in 14,737 Danish blood donors: results from the Danish Blood Donor Study. Transfusion. 2014 Mar;54(3 Pt 2):789-96.

8 Rigas AS, Pedersen OB, Magnussen K, Erikstrup $\mathrm{C}$, Ullum $\mathrm{H}$. Iron deficiency among blood donors: experience from the Danish Blood Donor Study and from the Copenhagen ferritin monitoring scheme. Transfus Med. 2019 Apr;29(Suppl 1):23-7.

9 Stern M, O’Meara A, Infanti L, Sigle JP, Buser A. Prognostic value of red blood cell parameters and ferritin in predicting deferral due to low hemoglobin in whole blood donors. Ann Hematol. 2012 May;91(5):775-80.
10 American Association of Blood Banks, Donor Iron Deficiency Risk-Based Decision-Making: Assesment Report [cited October 19, 2018]. Available from: https://www.aabb.org/ tm/Documents/AABB-Donor-Iron-Deficiency-RBDM-Assessment-Report-Supplemental-Material.pdf.

11 Sayers M, Centilli J. Contemplating the effect on blood availability if the interdonation interval of 56 days is prolonged. Transfusion. 2013 May;53(5):1132-6.

12 Cable RG, Glynn SA, Kiss JE, Mast AE, Steele WR, Murphy EL, et al.; NHLBI Retrovirus Epidemiology Donor Study-II (REDS-II). Iron deficiency in blood donors: the REDS-II Donor Iron Status Evaluation (RISE) study. Transfusion. 2012 Apr;52(4):702-11.

13 Karp JK, King KE. International variation in volunteer whole blood donor eligibility criteria. Transfusion. 2010 Feb;50(2):507-13.

14 American National Red Cross. Blood Services, Blood Donors Eligibility Criteria [cited October 19, 2018]. Available from: https:// www.redcrossblood.org/donate-blood/howto-donate/eligibility-requirements/eligibility-criteria-alphabetical.html.

15 European Directorate for the Quality of Medicine \& Health Care, Council of Europe. Guide to the Preparation, Use and Quality Assurance of Blood Components. Recommendation No.R (95) 15.17th Edition ed. 2013. Strasbourg, France.

16 Spencer BR, Bialkowski W, Creel DV, Cable RG, Kiss JE, Stone M, et al.; National Heart, Lung, and Blood Institute Recipient Epidemiology and Donor Evaluation Study-III (REDS-III) Program. Elevated risk for iron depletion in high-school age blood donors. Transfusion. 2019 May;59(5):1706-16.

17 Mast AE, Foster TM, Pinder HL, Beczkiewicz CA, Bellissimo DB, Murphy AT, et al. Behavioral, biochemical, and genetic analysis of iron metabolism in high-intensity blood donors. Transfusion. 2008 Oct;48(10):2197204.

18 Ganz T. Hepcidin, a key regulator of iron metabolism and mediator of anemia of inflammation. Blood. 2003 Aug;102(3):783-8.
19 Keshelashvili K, O'meara A, Stern M, Jirout Z, Pehlic V, Holbro A, et al. Adverse events and retention of donors of double red cell units by apheresis. Blood Transfus. 2016 Sep;14(5): 391-9.

20 Cable RG, Glynn SA, Kiss JE, Mast AE, Steele WR, Murphy EL, et al.; NHLBI Retrovirus Epidemiology Donor Study-II. Iron deficiency in blood donors: analysis of enrollment data from the REDS-II Donor Iron Status Evaluation (RISE) study. Transfusion. 2011 Mar; 51(3):511-22.

21 Högler W, Mayer W, Messmer C, Eibl G, Innerhofer P, Schönitzer D, et al. Prolonged iron depletion after allogeneic 2-unit RBC apheresis. Transfusion. 2001 May;41(5):6025.

22 Mendrone A Jr, Arrais CA, Almeida Neto C, Gualandro SF, Dorlhiac-Llacer PE, Chamone DA, et al. Impact of allogeneic 2-RBC apheresis on iron stores of Brazilian blood donors. Transfus Apheresis Sci. 2009 Aug;41(1):13-7.

23 Harrison JF. Automated red cell collectionquality and value. Transfus Med. 2006 Jun; 16(3):155-64.

24 González ML, Maia S, Mesquita P, Bessa M. Study of serum ferritin in donors of two red blood cells units collected by apheresis. Transfus Apheresis Sci. 2013 Oct;49(2):23843.

25 Kanias T, Stone M, Page GP, Guo Y, EndresDighe SM, Lanteri MC, et al.; NHLBI Recipient Epidemiology Donor Evaluation Study (REDS)-III Program. Frequent blood donations alter susceptibility of red blood cells to storage- and stress-induced hemolysis. Transfusion. 2019 Jan;59(1):67-78.

26 Bandyopadhyay S, Brittenham GM, Francis RO, Zimring JC, Hod EA, Spitalnik SL. Irondeficient erythropoiesis in blood donors and red blood cell recovery after transfusion: initial studies with a mouse model. Blood Transfus. 2017 Mar;15(2):158-64. 